\title{
Subcellular Localization of D-Glucanases in Bacteroides oralis Ig4a
}

\author{
By NOBUYOSHI TAKAHASHI, ${ }^{*}$ YOSHIKO SATOH ${ }^{1}$ AND \\ KENSHIRO TAKAMORI ${ }^{2}$ \\ ${ }^{1}$ Department of Oral Bacteriology, Tokyo Medical and Dental University School of Dentistry, \\ Yushima, Bunkyo-ku, Tokyo 113, Japan \\ ${ }^{2}$ Department of Oral Microbiology, Showa University School of Dentistry, Hatanodai, \\ Shinagawa-ku, Tokyo 142, Japan
}

(Received 20 September 1984; revised 21 December 1984)

\begin{abstract}
Three D-glucan-hydrolysing enzymes from Bacteroides oralis Ig4a have been isolated. Two of them are dextranases which hydrolyse $(1 \rightarrow 6)$ but not $(1 \rightarrow 3)$ linked $\alpha$-D-glucans; one (EC 3.2.1 .11, 1,6- $\alpha$-D-glucan 6-glucanohydrolase) is localized in the periplasm, and the other, which is an exo-enzyme (EC 3 2 .1 .70, 1,6- $\alpha$-D-glucan glucohydrolase), in the cytoplasm. The third is a mutanase (EC 3.2 . 1 .59, 1,3-(1,3;1,4)- $\alpha$-D-glucan 3-glucanohydrolase) that hydrolyses $(1 \rightarrow 3)$ but not $(1 \rightarrow 6)$ linked $\alpha$-D-glucans, and is present only in the cytoplasm.
\end{abstract}

\section{INTRODUCTION}

Extracellular polysaccharides, especially glucans, are considered to be important matrix substances in dental plaque (Gibbons \& Nygaard, 1968; Guggenheim \& Schroeder, 1967) and are thought to participate in the initiation of dental caries (Fitzgerald \& Jordan, 1968; Gibbons \& Banghart, 1967; Newbrun, 1976). D-Glucanases such as dextranase (EC 3.2.1.11, 1,6- $\alpha$-Dglucan 6-glucanohydrolase or EC 3.2.1 .70, 1,6- $\alpha$-D-glucan glucohydrolase) and mutanase (EC 3. 2. 1.59, 1,3-(1,3;1,4)- $\alpha$-D-glucan 3-glucanohydrolase) have been tested by a number of workers with the aim of eliminating the accumulation of dental plaque. Dextranase (Caldwell et al., 1971; König \& Guggenheim, 1968; Nyman et al., 1972) and mutanase (Guggenheim et al., 1972; Kelstrup et al., 1973; Simonson et al., 1983) were less effective in eliminating dental plaque when applied separately. The combined application of both enzymes has been reported to be effective in eliminating mature dental plaque in vivo (Guggenheim \& Haller, 1972; Staat et al., 1982; Takahashi et al., 1982). We have found that a strain of Bacteroides oralis Ig4a produces both dextranases and a mutanase and the present study was undertaken to determine the subcellular localization of these enzymes.

\section{METHODS}

Culture medium. Bacteroides oralis Ig4a (Takahashi, 1982) was used as a source of the D-glucanases. The cells were grown anaerobically in either trypticase soy broth (without dextrose, BBL) supplemented with $0.5 \%$ dextran (TS-D broth), or Luria broth supplemented with $0.5 \mathrm{~mm}$-isopropyl $\beta$-D-thiogalactoside.

Enzyme extract. Subcellular fractions were prepared by the osmotic shock method of Nossal \& Heppel (1966). After the osmotic shock step, the cells were suspended in $20 \mathrm{~mm}-\mathrm{Tris} / \mathrm{HCl}, \mathrm{pH} 7.0$, maintained at $0{ }^{\circ} \mathrm{C}$, and were disrupted using a Polytron type PT10/35 sonicator (Kinematica, Luzern, Switzerland) at maximum output for $5 \mathrm{~min}$. After removal of the unbroken cells by centrifugation at $3000 \mathrm{~g}$ for $10 \mathrm{~min}$ at $4{ }^{\circ} \mathrm{C}$, the supernatant was recentrifuged at $20000 \mathrm{~g}$ for $20 \mathrm{~min}$. The pellet was resuspended in $20 \mathrm{~mm}-\mathrm{Tris} / \mathrm{HCl}, \mathrm{pH} 7.0$ and washed twice in the same buffer; it was termed the membrane fraction to indicate membrane and/or membrane associated ribosomes that were not sedimented by the centrifugation at $3000 \mathrm{~g}$. The supernatant was then centrifuged once more at $120000 \mathrm{~g}$ for $120 \mathrm{~min}$, to separate the ribosomal and cytoplasmic fractions. The ribosomes were suspended

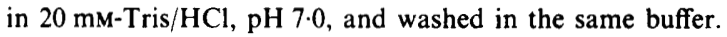

Spheroplasts were formed by treatment with lysozyme (Neu \& Heppel, 1964) for $15 \mathrm{~min}$ and stabilized by the addition of $\mathrm{MgCl}_{2}$ to give a concentration of $0.01 \mathrm{M}$. The spheroplasts were separated from the buffer $(20 \%, \mathrm{w} / \mathrm{v}$, 
sucrose, $30 \mathrm{~mm}$-Tris/ $\mathrm{HCl}, \mathrm{pH} \mathrm{7.0)}$ ) by centrifugation at $13000 \mathrm{~g}$ for $15 \mathrm{~min}$, and then osmotically lysed in cold distilled water. The suspension was centrifuged at $10000 \mathrm{~g}$ for $10 \mathrm{~min}$, and the supernatant from the lysed spheroplasts was collected. The pellets were resuspended in $10 \mathrm{~mm}-\mathrm{Tris} / \mathrm{HCl}, \mathrm{pH} 7 \cdot 0$, and sonicated. Samples of each fraction were dialysed for $24 \mathrm{~h}$ against $20 \mathrm{~mm}$-phosphate buffer, $\mathrm{pH} 7 \cdot 0$, and stored at $-20^{\circ} \mathrm{C}$.

Suhstrates. Pseudonigeran, a (1 $\rightarrow 3)-\alpha$-D-glucan, was extracted from mycelium of Aspergillus niger A TCC 16888 as described by Hasegawa et al. (1968), and was used for the assay of mutanase. Dextran T-2000, a (1 $\rightarrow 6)-\alpha-D-$ glucan, was purchased from Pharmacia, and was used as a substrate for the dextranase.

Enzlme assays. The D-glucan-hydrolysing activity in each fraction was assayed by measuring the release of reducing groups from the appropriate substrates (Somogyi, 1952). Alternatively the release of D-glucose was measured by using D-glucose oxidase (Dahlqvist, 1961). Unless otherwise noted, the reactions were performed by the addition of $0.5 \mathrm{ml}$ of a suitably diluted enzyme solution to $0.5 \mathrm{ml} 20 \mathrm{~mm}$-phosphate buffer, $\mathrm{pH} 7 \cdot 0$, containing $0.2 \%$ dextran, and incubating at $37^{\circ} \mathrm{C}$ for $30 \mathrm{~min}$ (Takahashi, 1982). The mutanase activity was estimated in the same way except that a $0.2 \%$ suspension of pseudonigeran was used as the substrate instead of dextran (Hasegawa et al., 1968). One unit of activity (U) was defined as the amount of enzyme which liberated $1 \mu \mathrm{mol}$ of reducing groups measured as glucose equivalents under standard assay conditions.

Miscellaneous procedures. Under standard assay conditions, protein was estimated by the Lowry method with bovine serum albumin as the standard. The purity of the subcellular fractions (Heppel, 1971) was assessed by assaying for alkaline phosphatase (Malamy \& Horecker, 1961), principally a periplasmic enzyme, and $\beta$-Dgalactosidase (Zipser, 1963), principally a cytoplasmic enzyme. The various D-glucan-hydrolysing enzymes in the cytoplasmic and periplasmic fractions of $B$. oralis Ig4a were isolated by sequential chromatography on DEAEcellulose and Bio-Gel A-0.5 m (Bio-Rad) as described previously (Takahashi, 1982).

\section{RESULTS}

When $B$. oralis $\operatorname{Ig} 4 \mathrm{a}$ was grown in TS-D broth after $48 \mathrm{~h}$, most of the dextranase activity (approximately $75 \%$ ) was recovered in the culture supernatant and the rest remained in the cells (Fig. 1); in contrast, the bulk of the mutanase activity remained bound to the cells. Small amounts of both enzymes were detected in the culture supernatant at the late stationary phase of growth; however, no mutanase activity was detected in the buffer used for washing intact cells.

The intracellular localization of these enzymes was investigated by using two cell fractionation procedures. When $B$. oralis Ig4a cells were converted to spheroplasts by osmotic shock, 60 to $70 \%$ of the cell-bound dextranase was released into the buffer within $10 \mathrm{~min}$. Thereafter no more dextranase was released but some (20 to $30 \%$ ) remained bound to the spheroplasts. This dextranase was of high specific activity and could not be removed from the spheroplasts by washing. Almost all of the mutanase activity ( $>95 \%$ ) remained associated with the spheroplasts. Subcellular fractions were obtained by centrifugation, and the various enzyme activities were measured. Most of the dextranase activity was detected in both the periplasmic and cytoplasmic fractions, but not in the membrane or ribosomal fractions (Table 1). In contrast, $70 \%$ of the mutanase activity was found in the cytoplasm.

We determined the extent of liberation of the cell-bound D-glucanases during spheroplast formation and spheroplast lysis by using marker enzymes. Alkaline phosphatase was used as a marker enzyme for the periplasmic space, while $\beta$-D-galactosidase was used as a marker for the cytoplasm. If a periplasmic enzyme is bound tightly to components of the cell surface outside the cytoplasmic membrane, it could be retained by cells subjected to osmotic shock. Activities released from the cells during spheroplast formation and those released only upon the subsequent lysis of the spheroplasts were assayed. Alkaline phosphatase was largely released during spheroplast formation, whereas $\beta$-D-galactosidase was retained (Table 2). Similarly, over $60 \%$ of the total dextranase activity was released into the spheroplast-forming buffer, the rest $(20-30 \%)$ remaining bound to the spheroplast. In contrast, mutanase behaved like a cytoplasmic enzyme and was retained inside the spheroplasts.

The results obtained with the dextranase suggested that there might be two forms of this enzyme, each localized within a different region of the cell. In order to examine this possibility, enzymes in the periplasmic and cytoplasmic fractions were separated by sequential chromatography on DEAE-cellulose and Bio-Gel A-0.5 m columns (Takahashi, 1982). Fractions containing enzyme activity were pooled, concentrated in an Amicon pressure cell with a Diaflo PM-10 membrane, and dialysed against $20 \mathrm{mM}$-phosphate buffer, $\mathrm{pH} 7 \cdot 0$. The retentate 


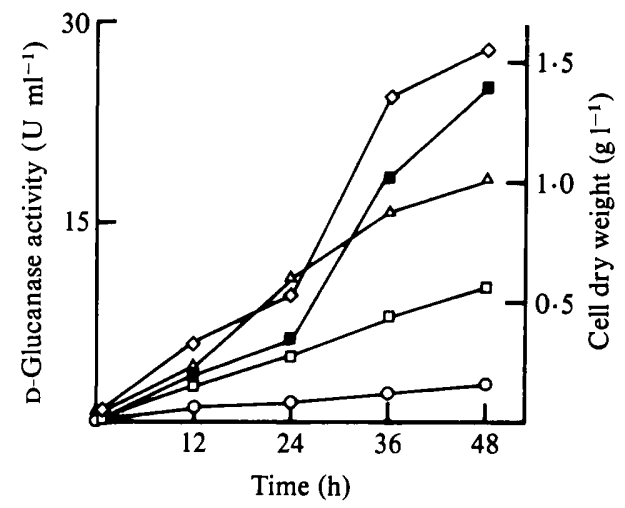

Fig. 1. Production of dextranase and mutanase by $B$. oralis Ig4a grown in TS-D broth. Five 1 litre culture bottles containing $800 \mathrm{ml}$ of this medium were incubated anaerobically with $5 \mathrm{ml}$ preincubated bacteria for the time indicated. The total content of one culture bottle was used for the determinations at each time point: dextranase $(\diamond)$ and mutanase $(O)$ in the culture medium and cell-associated dextranase $(\square)$ and mutanase $(\triangle)$ and cell dry weight $(\boldsymbol{\square})$ were measured.

Table 1. D-Glucanase localization in fractions prepared by osmotic lysis of Bacteroides oralis Ig4a

\begin{tabular}{|c|c|c|c|c|c|c|c|c|}
\hline \multirow[b]{2}{*}{$\begin{array}{l}\text { Subcellular } \\
\text { fraction }\end{array}$} & \multicolumn{2}{|c|}{$\begin{array}{l}\text { Enzyme activity } \\
\text { [U (mg cell dry wt } \\
\text { or equivalent })^{-1} \text { ] }\end{array}$} & \multicolumn{2}{|c|}{$\begin{array}{l}\text { Activity* } \\
(\%)\end{array}$} & \multicolumn{2}{|c|}{$\begin{array}{l}\text { Specific activity } \\
{\left[\mathrm{U}(\mathrm{mg} \text { protein })^{-1}\right]}\end{array}$} & \multicolumn{2}{|c|}{$\begin{array}{l}\text { Activity of marker } \\
\text { enzymes*+ }(\%)\end{array}$} \\
\hline & $\begin{array}{l}\text { Dextran- } \\
\text { ase }\end{array}$ & $\begin{array}{l}\text { Mutan- } \\
\text { ase }\end{array}$ & $\begin{array}{l}\text { Dextran- } \\
\text { ase }\end{array}$ & $\begin{array}{l}\text { Mutan- } \\
\text { ase }\end{array}$ & $\begin{array}{l}\text { Dextran- } \\
\text { ase }\end{array}$ & $\begin{array}{l}\text { Mutan- } \\
\text { ase }\end{array}$ & $\begin{array}{l}\text { phos- } \\
\text { phatase }\end{array}$ & $\begin{array}{l}\beta \text {-Galacto- } \\
\text { sidase }\end{array}$ \\
\hline Stage I shock fluid & $5 \cdot 2$ & $1 \cdot 2$ & 8 & 5 & 0.5 & 0.01 & $5 \cdot 2$ & $1 \cdot 1$ \\
\hline Periplasmic fraction & $33 \cdot 4$ & $1 \cdot 0$ & 53 & 4 & $8 \cdot 0$ & 0.02 & $87 \cdot 3$ & $5 \cdot 4$ \\
\hline Cytoplasmic fraction & $23 \cdot 0$ & $19 \cdot 6$ & 37 & 72 & $7 \cdot 2$ & $5 \cdot 7$ & $4 \cdot 5$ & $81 \cdot 0$ \\
\hline Membrane fraction & $0 \cdot 4$ & 3.8 & 1 & 14 & $0 \cdot 1$ & $0 \cdot 8$ & $1 \cdot 6$ & $1 \cdot 5$ \\
\hline Ribosome fraction & 0.7 & $1 \cdot 5$ & 1 & 5 & $0 \cdot 3$ & $0 \cdot 1$ & 1.4 & $11 \cdot 0$ \\
\hline
\end{tabular}

* Activities are expressed as a percentage of the total activity of the five fractions.

$\dagger$ Overall recovery of alkaline phosphatase was $95.3 \%$ and of $\beta$-galactosidase, $92.5 \%$.

Table 2. Release of enzymes after spheroplast formation of Bacteroides oralis Ig4a

\begin{tabular}{|c|c|c|c|c|c|c|}
\hline \multirow[b]{3}{*}{ Fraction } & \multirow{2}{*}{\multicolumn{2}{|c|}{$\begin{array}{c}\text { Activity of } \\
\text { glucanases }(\%)\end{array}$}} & \multirow{2}{*}{\multicolumn{2}{|c|}{$\begin{array}{l}\text { Specific activity } \\
\left.\text { [U (mg protein) })^{-1}\right]\end{array}$}} & \multicolumn{2}{|c|}{$\begin{array}{c}\text { Activity of } \\
\text { marker enzymes }(\%)\end{array}$} \\
\hline & & & & & \multirow{2}{*}{$\overbrace{\begin{array}{c}\text { Alkaline } \\
\text { phosphatase }\end{array}}$} & \multirow{2}{*}{$\begin{array}{c}\beta \text {-Galacto } \\
\text { sidase }\end{array}$} \\
\hline & Dextranase & Mutanase & Dextranase & Mutanase & & \\
\hline $\begin{array}{l}\text { Supernatant, after removal } \\
\text { of spheroplasts }\end{array}$ & 62.8 & $11 \cdot 1$ & 16.5 & 0.8 & 92.5 & $15 \cdot 7$ \\
\hline $\begin{array}{l}\text { Supernatant, osmotically } \\
\text { lysed spheroplasts }\end{array}$ & 28.0 & $81 \cdot 8$ & $12 \cdot 1$ & 6.8 & $7 \cdot 1$ & $81 \cdot 4$ \\
\hline Sonic extract of pellet from & $9 \cdot 2$ & $7 \cdot 1$ & $1 \cdot 2$ & 0.7 & $0 \cdot 4$ & 2.9 \\
\hline
\end{tabular}

was applied to a column of DEAE-cellulose equilibrated with the same buffer, and eluted with $400 \mathrm{ml}$ of a linear salt gradient $(0-0.4 \mathrm{M}-\mathrm{NaCl})$. As described previously (Takahashi, 1982), this step resulted in the separation of two dextranases, which were eluted by $0.18 \mathrm{M}-\mathrm{NaCl}(\mathrm{En}-\mathrm{I})$ and by $0.25 \mathrm{M}-\mathrm{NaCl}$ (En-II). A minor peak comprising $10 \%$ of the total dextranase activity in the periplasmic fraction was thought to be caused by contamination with cytoplasmic fractions (Fig. $2 a, b$ ). The active fractions corresponding to En-I or En-II were pooled and chromatographed on a Bio-Gel A-0.5 m column equilibrated with $20 \mathrm{~mm}$-phosphate buffer, $\mathrm{pH} 7 \cdot 0$. The dextranases in the periplasmic and cytoplasmic fractions had different molecular weights (Fig. $2 c, d$ ). 


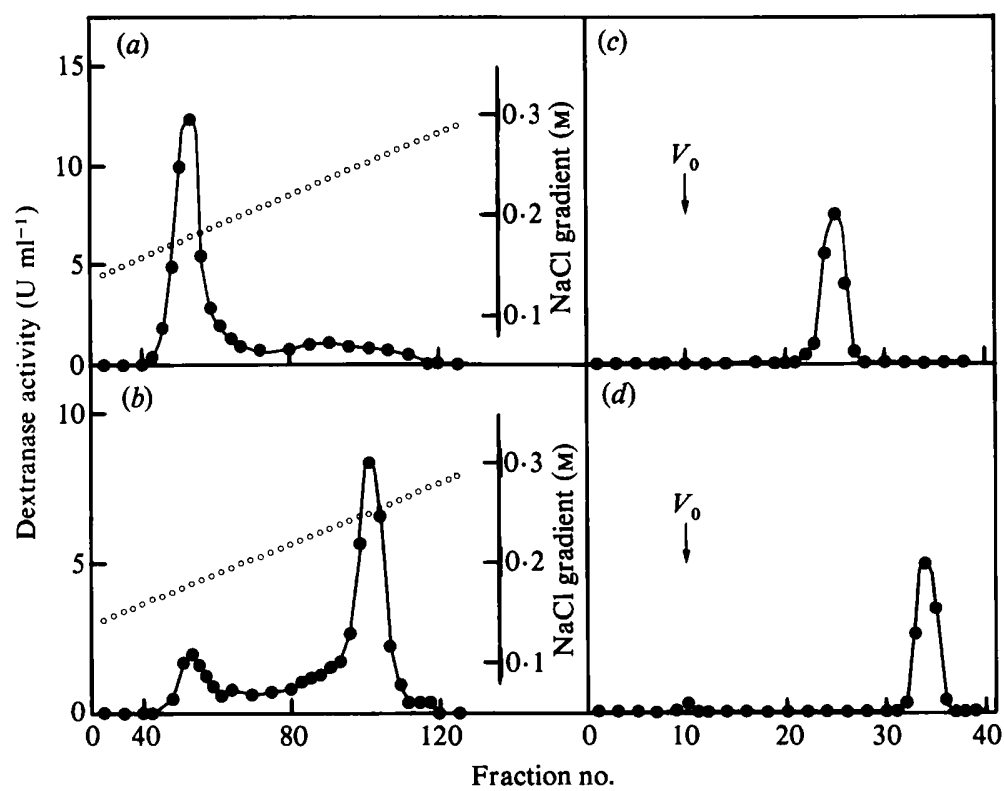

Fig. 2. ( $a, b)$. DEAE-cellulose column chromatography of the periplasmic $(a)$ and cytoplasmic $(b)$ dextran-hydrolysing activities. The cellular fractions were prepared from $B$. oralis $\lg 4 \mathrm{a}$ as described in the text. Both the periplasmic and cytoplasmic fractions were concentrated by ultrafiltration using a PM-10 membrane and dialysed against $20 \mathrm{~mm}$-phosphate buffer ( $\mathrm{pH} 7 \cdot 0$ ). The retentate was applied to a DEAE-cellulose column. The enzyme was eluted with a linear $\mathrm{NaCl}$ gradient $(0-0.4 \mathrm{M})$ in $400 \mathrm{ml}$ of $20 \mathrm{~mm}$-phosphate buffer, pH 7.0, and $3 \mathrm{ml}$ fractions were collected. $(c, d)$ The active fractions eluted from the DEAE-cellulose columns $(a)$ and $(b)$ respectively were pooled, concentrated, and submitted to chromatography on Bio-Gel A-0.5 m columns equilibrated and developed with 20 mM-phosphate buffer $(\mathrm{pH} 7 \cdot 0)$. $V_{0}$, void volume (blue dextran 2000$)$.

\section{DISCUSSION}

We have found that the dextranase of Bacteroides oralis $\operatorname{Ig} 4 \mathrm{a}$ is localized in both the periplasmic and cytoplasmic regions of the cell. About $75 \%$ of the dextranase activity of $B$. oralis Ig $4 \mathrm{a}$ is found extracellularly, but about $60 \%$ of the cell-bound enzyme is released when spheroplasts are prepared. In a previous study (Takahashi, 1982), we reported that $B$. oralis Ig4a produces two kinds of dextran-hydrolysing enzyme, designated as En-I (mol. wt 52000) and En-II (mol. wt 44000). The former is an endo-dextranase that produces oligosaccharides, whereas the latter is an exo-enzyme producing glucose as the sole end-product (Takahashi, 1982). The dextranase localized in the periplasmic space corresponded to En-I, and the dextranase localized in the cytoplasm corresponded to En-II.

Walker et al. (1981) reported that Streptococcus mutans produces two types of dextranase; one was an exo-type of enzyme which was found mainly intracellularly and was almost undetectable in the culture filtrate, whereas the other was an endodextranase which was released in the early exponential phase of growth. Furthermore, Staat \& Schachtele (1976) reported that Bacteroides ochraceus isolated from dental plaque produced exo- and endo-dextranases with distinct $\mathrm{pH}$ optima. However, the localization and physiological function of those two types of dextranase were not described.

The mutanase of $B$. oralis Ig4a was exclusively localized in the cytoplasm, as neither the culture supernatant nor the spheroplast-forming buffer had detectable enzyme activity. Linder et al. (1983) reported that the dextranase of Streptococcus mitis was localized in the cytoplasm, and was not released into the medium when cells were converted to spheroplasts by the cell walldegrading M-1 enzyme isolated from Streptomyces globisporus. However, Heppel (1971) obtained evidence by use of the osmotic shock technique that many hydrolytic enzymes are localized in the periplasm of Gram-negative bacteria. An accumulated enzyme pool could be 
held between the cytoplasmic membrane and an outer membrane (periplasmic space), either bound directly to some component or by being unable to diffuse through the complex outer surface layer (Heppel, 1971; Neu \& Heppel, 1965). However, there have been few reports on the localization of polysaccharidases on the surface of Gram-negative bacteria. The mechanism of degradation of exogenous substrates that are unable to pass through the inner membrane has not been clarified. The different subcellular localization of these enzymes may suggest that the polysaccharides in dental plaque are hydrolysed by extracellular enzymes such as En-I to produce oligosaccharides that are small enough to enter the cells. Intracellular polysaccharidases (En-II and mutanase) then further hydrolyse these oligosaccharides to monosaccharides, thus permitting the use of parts of the dental plaque polysaccharide for growth. Therefore, these enzymes may reduce the accumulation of dental plaque and may prove to be useful for the prevention of dental caries in humans.

\section{REFERENCES}

Caldwell, R. C., Sandham, H. J., Mann, W. V., JR, FinN, S. B. \& Formicola, A. J. (1971). The effect of a dextranase mouthwash on dental plaque in young adults and children. Journal of the American Dental Association 82, 124-131.

DAHLQVIST, A. (1961). Determination of maltose and isomaltose activities with a glucose-oxidase reagent. Biochemical Journal 80, 547-551.

Fitzgerald, R. J. \& Jordan, H. V. (1968). Polysaccharide-producing bacteria and caries. In Art and Science of Dental Caries Research, pp. 79-86. Edited by H. R. Harris. New York: Academic Press.

Gibbons, R. J. \& Banghart, S. S. S. (1967). Synthesis of extracellular dextran by cariogenic bacteria and its presence in human dental plaque. Archives of Oral Biology 12, 11-24.

GibBons, R. J. \& NygaARD, M. (1968). Synthesis of insoluble dextran and its significance in the formation of gelatinous deposits by plaque-forming streptococci. Archives of Oral Biology 13, 1249-1262.

Guggenheim, B. \& Haller, R. (1972). Purification and properties of an $\alpha$-(1,3)-glucanohydrolase from Trichoderma harzianum. Journal of Dental Research 51, 394-402.

Guggenheim, B. \& Schroeder, H. E. (1967). Biochemical and morphological aspects of extracellular polysaccharides produced by cariogenic streptococci. Helvetica odontologica acta 11, 131-152.

Guggenheim, B., Regolati, B. \& MühlemanN, H. R. (1972). Caries and plaque inhibition by mutanase in rats. Caries Research 6, 289-297.

Hasegawa, S., Nordin, J. H. \& Kirkwood, S. (1968). Enzymes that hydrolyze fungal cell wall polysaccharides. I. Purification and properties of an endo- $\alpha-D-$ (1,3)-glucanase from Trichoderma viride. Journal of Biological Chemistry 244, 5460-5470.

HEPPEL, L. A. (1971). The concept of periplasmic membrane. In Structure and Function of Biological Membranes, pp. 223-247. Edited by L. I. Rothfield. New York: Academic Press.

Kelstrup, J., Funder-Nielsen, T. D. \& Møller, E. N. (1973). Enzymatic reduction of the colonization of Streptococcus mutans in human dental plaque. Acta odontologica scandinavica 31, 249-253.

KöNIG, K. G. \& GugGenheIM, B. (1968). In vivo effects of dextranase on plaque and caries. Helvetica odontologica acta 12, 48-55.

Linder, L., ANDERsSon, C., Sund, M.-L. \& SHOCK-
MAN, G. D. (1983). Protoplast formation and localization of enzymes in Streptococcus mitis. Infection and Immunity 40, 1146-1154.

Malamy, M. \& Horecker, B. L. (1961). The localization of alkaline phosphatase in $E$. coli $\mathrm{K} 12$. Biochemical and Biophysical Research Communications 5, 104-108.

NeU, H. C. \& HePpel, L. A. (1964). The release of ribonuclease into the medium when Escherichia coli cells are converted to spheroplasts. Journal of Biological Chemistry 239, 3893-3900.

NeU, H. C. \& HePpel, L. A. (1965). The release of enzymes from Escherichia coli by osmotic shock and during the formation of spheroplasts. Journal of Biological Chemistry 240, 3685-3692.

Newbrun, E. (1976). Polysaccharide synthesis in plaque. In Microbial Aspects of Dental Caries, pp. 649-664. Edited by H. M. Stiles, W. J. Loesche \& T. C. O'Brien. Washington, DC: Information Retrieval.

Nossal, N. G. \& Heppel, L. A. (1966). The release of enzymes by osmotic shock from Escherichia coli in exponential phase. Journal of Biological Chemistry 241, 3055-3062.

Nyman, S., Lindhe, J. \& Janson, J. (1972). The effect of bacterial dextranase on human dental plaque formation and gingivitis development. Odontologisk revy $23,243-252$.

Simonson, L. G., LAmberts, B. L., Reiher, D. A. \& WALTER, R. G. (1983). Prevention of dental caries in hamsters by an endo-1,3- $\alpha$-D-glucanase. Journal of Dental Research 62, 395-397.

SoMOGYI, M. (1952). Notes on sugar determination. Journal of Biological Chemistry 195, 19-23.

StaAt, R. H. \& Schachtele, C. H. (1976). Analysis of the dextranase activity produced by an oral strain of Bacteroides ochraceus. Journal of Dental Research 55, $1103-1110$.

StaAt, R. H., Langley, S. D. \& Swenson, J. I. (1982). In vivo relationships of the dextran-degrading oral microbiota to Streptococcus mutans and caries experience. Caries Research 16, 18-25.

TAKAHASHI, N. (1982). Isolation and properties of dextranases from Bacteroides oralis Ig4a. Microbiology and Immunology 26, 375-386.

Takahashi, N., Horikawa, T., Mizuno, F., YamaMOTO, A. \& TAKAMORI, K. (1982). Effect of glucanases of Bacteroides oralis Ig4a on artificial 
plaque of Streptococcus mutans. Japanese Journal of Oral Biology 24, 1058-1060.

Walker, G. J., Pulkownik, A. \& Morrey-Jones, J. G. (1981). Metabolism of the polysaccharides of human dental plaque: release of dextranase in batch cultures of Streptococcus mutans. Journal of General Microbiology 127, 201-208.

ZIPSER, D. (1963). A study of the urea-produced subunits of $\beta$-galactosidase. Journal of Molecular Biology 7, 113-121. 